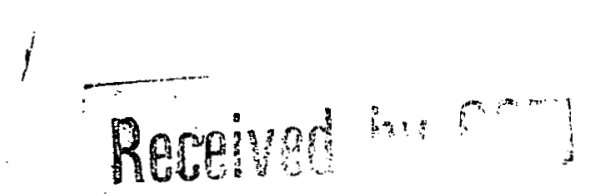

NOV 241986

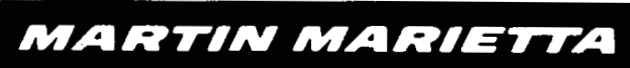

3

\title{
THE SOLUBILITY OF URANIUM HEXAFLUORIDE IN PERFLUOROETHERS
}

\author{
E. J. Barber
}

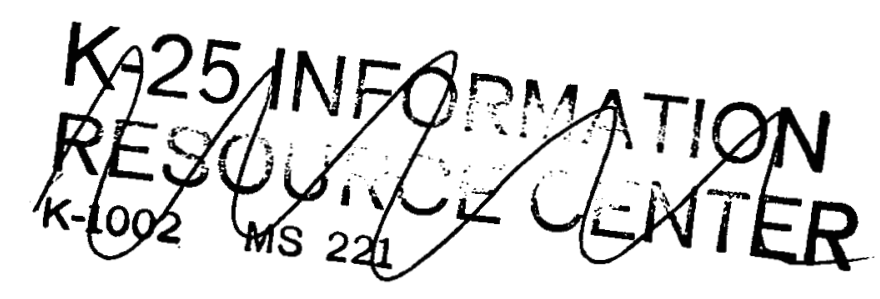

JULY 1984

OPERATED BY

MARTIN MARIETTA ENERGY SYSTEMS, INC.

FOR THE UNITED STATES

DISTRIBUTION OF THIS DOCUMENT IS UNLIMITED

DEPARTMENT OF ENERGY 


\section{DISCLAIMER}

This report was prepared as an account of work sponsored by an agency of the United States Government. Neither the United States Government nor any agency Thereof, nor any of their employees, makes any warranty, express or implied, or assumes any legal liability or responsibility for the accuracy, completeness, or usefulness of any information, apparatus, product, or process disclosed, or represents that its use would not infringe privately owned rights. Reference herein to any specific commercial product, process, or service by trade name, trademark, manufacturer, or otherwise does not necessarily constitute or imply its endorsement, recommendation, or favoring by the United States Government or any agency thereof. The views and opinions of authors expressed herein do not necessarily state or reflect those of the United States Government or any agency thereof. 


\section{DISCLAIMER}

Portions of this document may be illegible in electronic image products. Images are produced from the best available original document. 


\section{DISCLAIMER}

This report was prepared as an account of work sponsored by an agency of the United States Government. Neither the United States Government nor any agency thereof, nor any of their employees, makes any warranty, express or implied, or assumes any legal liability or responsibility for the accuracy, completeness, or usefulness of any information, apparatus, product, or process disclosed, or represents that its use would not infringe privately owned rights. Reference herein to any specific commercial product, process, or service by trade name, trademark, manufacturer, or otherwise, does not necessarily constitute or imply its endorsement, recommendation, or favoring by the United States Government or any agency thereof. The views and opinions of authors expressed herein do not necessarily state or reflect those of the United States Government or any agency thereof. 


\section{$5 / 6$}

CONTENTS

Page

INTRODUCTION...................................

BASIC SOLUBILITY RELATIONSHIPS $\ldots \ldots \ldots \ldots \ldots \ldots \ldots \ldots \ldots \ldots \ldots \ldots$

ESTIMATED SOLUBILITY OF UF $_{6}$ IN TWO POLYPERFLUOROETHERS $\ldots \ldots \ldots \ldots \ldots$

COMPARISON TO UF 6 SOLUBILITY IN OTHER FLUOROCARBONS........... 10

EFFECT OF DISSOLVED UF 6 ON THE OPERATING PRESSURE OF A

ROTARY SEAL VACUUM PUMP.......................... 11

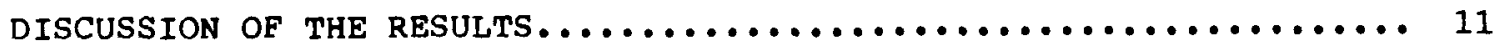

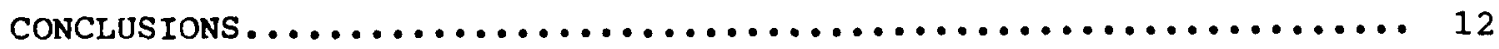

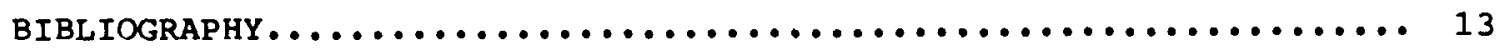

APPENDIX A. Physical and Thermodynamic Data Required for Estimation of the Solubility of Uranium Hexafluoride in Krytox

$143 \mathrm{AC}$ and Fomblin Y25 Fluids................. 15

APPENDIX B. Solubility of $\mathrm{UF}_{6}$ in Krytox $143 \mathrm{AC}$ and Fomblin $\mathrm{Y} 25$

Fluids at $160,150,120$, and $77^{\circ} \mathrm{F} \ldots \ldots \ldots \ldots \ldots \ldots \ldots . \ldots \ldots$

APPENDIX C. The Solubility of $\mathrm{UF}_{6}$ in Fluorocarbon oil C-2144

and in MFL Oil (Polychlorotrifluoroethylene)........ 25 


\section{INTRODUCTION}

The polyperfluoroethers are compatible with uranium hexafluoride $\left(U F_{6}\right.$ ) and are suitable for use in diffusion pumps and in mechanical vacuum pumps which rely on an oil as both the lubricant and the seal. The $\mathrm{UF}_{6}$ is soluble in all fluids with which it is compatible. Because a number of vacuum pumps in the BOP facilities of the GCEP plant employ these perfluoroether oils as the working fluid and have oil chambers which are large, * questions have been raised as to the relationships governing the solubility of $\mathrm{UF}_{6}$ in these materials and the maximum quantities of $U_{6}$ which could be dissolved in these oils under credible accident conditions. This report summarizes these solubility relations and the interaction of the $\mathrm{UF}_{6}$ solubility and the pumping capability of this type of vacuum pump. It will be shown that, whereas the solubility of $\mathrm{UF}_{6}$ in Fomblin $\mathrm{Y}_{25}$ fluoroether fluid under a UF 6 pressure of 760 torr and at the pump operating temperature of $160^{\circ} \mathrm{F}$ is about $500 \mathrm{~g}$ of $U_{6}$ per liter of oil, the system controls are such as to isolate the system from the pumps before the quantity of $\mathrm{UF}_{6}$ dissolved in the perfluoroether exceeds about $10 \mathrm{~g}$ of $\mathrm{UF}_{6}$ per liter of oil. .

\section{BASIC SOLUBILITY RELATIONSHIPS}

The solubility of $\mathrm{UF}_{6}$ in fluorocarbons is reasonably close to ideal ${ }^{l}$ and an approximation of the solubility can be made using Raoult's law which states that

$$
\bar{P}_{1}=x_{1} P_{1}^{\circ}
$$

where $\bar{P}_{1}$ is the partial pressure of component 1 ,

$$
\begin{aligned}
& x_{1} \text { is the mol fraction of component } 1 \text { and } \\
& p^{\circ} 1 \text { is the vapor pressure of pure liquid component } 1 \text {. }
\end{aligned}
$$

In actual practice Raoult's law is never precisely obeyed and a proportionality factor called the activity coefficient is employed to make the law exact; namely,

*While the pump oil chambers of some of the pumps have a capacity of $40 \mathrm{~L}$ of fluid, the chambers do not have to be filled for the pumps to operate satisfactorily. For this reason the quantity of oil in each pump can be limited, without adverse effects, to $27 \mathrm{~L}$ by administrative control. 


$$
\bar{P}_{1}=\gamma_{1} x_{1} P_{1}^{\circ}
$$

where $\gamma_{1}$ is the activity coefficient for component 1 .

Thus, it is apparent that the solubility of a volatile or gaseous component (or solute) in a system in which the second component (or solvent) is essentially not volatile is proportional to the relative pressure of the volatile component; i.e.,

$$
x_{1}=\bar{P}_{1} / \gamma_{1} P_{1}^{\circ}
$$

where $\bar{P}_{1} / P^{\circ}{ }_{1}$ is defined as the relative pressure $x_{1}$ of component 1 .

Equation 3 is readily evaluated if the activity coefficient can either be assumed to be independent of $x_{1}$ which is normally not the case or an analytic expression may be developed to evaluate it. Hildebrand and scott $^{2}$ developed an expression which has proven very reliable in estimating activity coefficients in systems of this kind from the earlier efforts of Hildebrand, Scatchard, Flory, and Huggins $3,4,5,6,$. This expression is

$$
\text { In } \gamma_{1}=\ln \left(\theta_{1} / x_{1}\right)+v_{1} \theta_{2}^{2}\left(\delta_{1}-\delta_{2}\right)^{2} / R T-\theta_{2}\left(v_{1} / v_{2}-1\right)
$$

where $\delta_{1}$ is the activity coefficient of component 1 ,

$x_{1}$ is the mol fraction of component 1 ,

$\theta_{1}$ is the volume fraction of component 1 defined as

$$
\theta_{1}=x_{1} v_{1} /\left(x_{1} v_{1}+x_{2} v_{2}\right) \text {, }
$$

$v_{1}$ and $v_{2}$ are the molar volumes of components 1 and 2 ,

$\theta_{2}$ is the volume fraction of component 2 ,

$R$ is the universal gas constant in appropriate units,

$T$ is the temperature in Kelvin, and

$\delta_{1}$ and $\delta_{2}$ are the solubility constant parameters or the "cohesive energy densities" of the components. 
The solubility parameters are defined by the relations

$$
\delta_{1}^{2}=\left(\Delta \mathrm{E}_{1}^{\mathrm{vap}} / \mathrm{V}_{1}\right) \text { and } \delta_{2}^{2}=\left(\Delta \mathrm{E}_{2}^{\mathrm{vap}} / \mathrm{V}_{2}\right)
$$

where $\Delta E_{1}^{\text {vap }}$ and $\Delta E_{2}^{\text {vap }}$

are the internal energies of vaporization and are frequently estimated by the relation

$\Delta E^{\text {vap }}=\Delta H^{\text {vap }}-R T$ in which $\Delta H^{\text {vap }}$ is the heat of vaporization.

To solve Equation 2 for $x_{1}$, it is noted that

$$
\gamma_{1} x_{1}=\bar{P}_{1} / P_{1}^{\circ}
$$

and that the value of the right hand side of Equation 5 is fixed for a given temperature and partial pressure of the solute. Now using an initial value for $x_{1}$ from Equation 1 and Equation 4 to evaluate $r_{1}$, an improved value of $x_{1}$ is obtained. By repeating the cycle with each new value of $x_{1}$, the difference between

$$
Y_{1} x_{1} \text { and } \vec{P}_{1} / P_{1}
$$

can be made arbitrarily small. The last value of $x_{1}$ so calculated gives the mol fraction of $\mathrm{UF}_{6}$ in the solvent for the given relative pressure and temperature.

The solubility in terms of $g \mathrm{UF}_{6}$ dissolved per liter of solvent is obtained from the mol fraction $x_{1}$ for $U F_{6}$ by the relation

$$
z=\left[x_{1} /\left(1-x_{1}\right)\right] *\left[M_{U F_{6}} / V_{s}\right] *[1000]
$$

or

$$
z=\left[x_{1} /\left(1-x_{1}\right)\right] *\left[M_{U F_{6}} / M_{s}\right] *\left[1000 \rho_{s}\right]
$$

where $z$ is the solubility in terms of $g^{U} \mathrm{UF}_{6}$ per liter of oil,

$x_{1}$ is mol fraction of component 1 (or UF6),

$M_{U_{6}}$ and $M_{S}$ are the molecular weights of $U_{6}$ and the solvent,

$v_{s}$ is the molar volume of the soivent equal to $M_{s} / \sigma_{s}$, and

$\rho_{\mathbf{s}}$ is the density of the solvent.

In the systems under consideration enough data are available to estimate all the values needed to solve the equations and an experimental value for the solubility has been determined which will permit estimation of the reliability of the calculations. The vapor 
pressures, heats of vaporization, molecular weights, densities, and solubility parameters needed are given or are estimated from existing data in Appendix $A$.

ESTIMATED SOLUBILITY OF UF 6 IN TWO POLYPERFLUOROETHERS

The solubility of $\mathrm{UF}_{6}$ in the polyperfluoroethers, Krytox $143 \mathrm{AC}$ Fluid (referred to hereafter as krytox AC) manufactured by $E$. I. Dupont de Nemours and Co. and Fomblin Y 25 Fluid manufactured by Montedison, has been estimated using the method described in the preceding section. The results, are tabulated in Appendix $B$ and are shown graphically in Figures 1, 2, and 3. Figure 1 shows the solubility in both liquids as a function of the relative pressure of $\mathrm{UF}_{6}$. The nature of the spread in the solubility data indicates that, in addition to the dependence on the relative pressure, there is a second order perturbation due to the temperature at a given relative pressure. Figures 2 and 3 illustrate the solubility of $\mathrm{UF}_{6}$ in the Krytox $A C$ and Fomblin Y25 fluids as functions of the temperature and partial pressure of the UF6. Also shown on these figures is the measured solubility of $\mathrm{UF}_{6}$ in Fomblin Y25 fluid. As will be demonstrated from experimental measurements on perfluorocarbon and polychlorotrifluoroethylene oils, the estimated solubilities of these perfluoroether liquids are in excellent agreement with the measured value and have the proper dependence on the partial pressure of $\mathrm{UF}_{6}$ and the temperature.

To a first approximation the solubility of $\mathrm{UF}_{6}$ in these liquids at a given temperature is directly dependent on the partial pressure of the $\mathrm{UF}_{6}$ over the oil. The solubility varies from less than a gram of $\mathrm{UF}_{6}$ per liter at 2 torr to approximately $700 \mathrm{~g}$ of $\mathrm{UF}_{6}$ per liter at atmospheric pressure and $150^{\circ} \mathrm{F}$ in Fomblin Y25 fluid. The solubility in Krytox $A C$ fluid is a little lower being less than $500 \mathrm{~g}$ of UF 6 per liter at a $\mathrm{UF}_{6}$ pressure of 760 torr at $150^{\circ} \mathrm{F}$. The experimental solubility of $\mathrm{UF}_{6}$ in Fomblin Y25 fluid at $150^{\circ} \mathrm{F}$ and 100 torr partial pressure of UF 6 is $36.2 \mathrm{~g}$ of $\mathrm{UF}_{6}$ per liter ${ }^{7}$.

\section{COMPARISON TO UF 6 SOLUBILITY IN OTHER FLUOROCARBONS}

The solubility of $\mathrm{UF}_{6}$ in a perfluorocarbon oil designated as C-2144 having the empirical formula $\mathrm{CF}_{3}\left(\mathrm{CF}_{2}\right)_{19} \mathrm{CF}_{3}$ (mol wt $=1088$ ) was experimentally determined at $S A M$ labs at 140,180 , and $212^{\circ} \mathrm{F} .{ }^{8}$ These data are listed in Appendix $C$ and compared to the solubility data on Fomblin Y25 fluid in Figures 4 and 5. Also shown are similar data for the solubility of $\mathrm{UF}_{6}$ in an.MFL oil (chlorotrifluoroethylene polymer) of molecular weight $790 \pm 30$ at $100,140,180,212$, and $220^{\circ} \mathrm{F} .{ }^{9}$ These data are also tabulated in Appendix $C$. Errors in measuring the solubility of $\mathrm{UF}_{6}$ in these oils are essentially as large as the difference between values estimated for the solubility of $\mathrm{UF}_{6}$ in the two perfluoroethers. Figure 5 which shows the dependence of the UF 6 solubility on the 
DwG. NO. K/G-84-2093

(U)

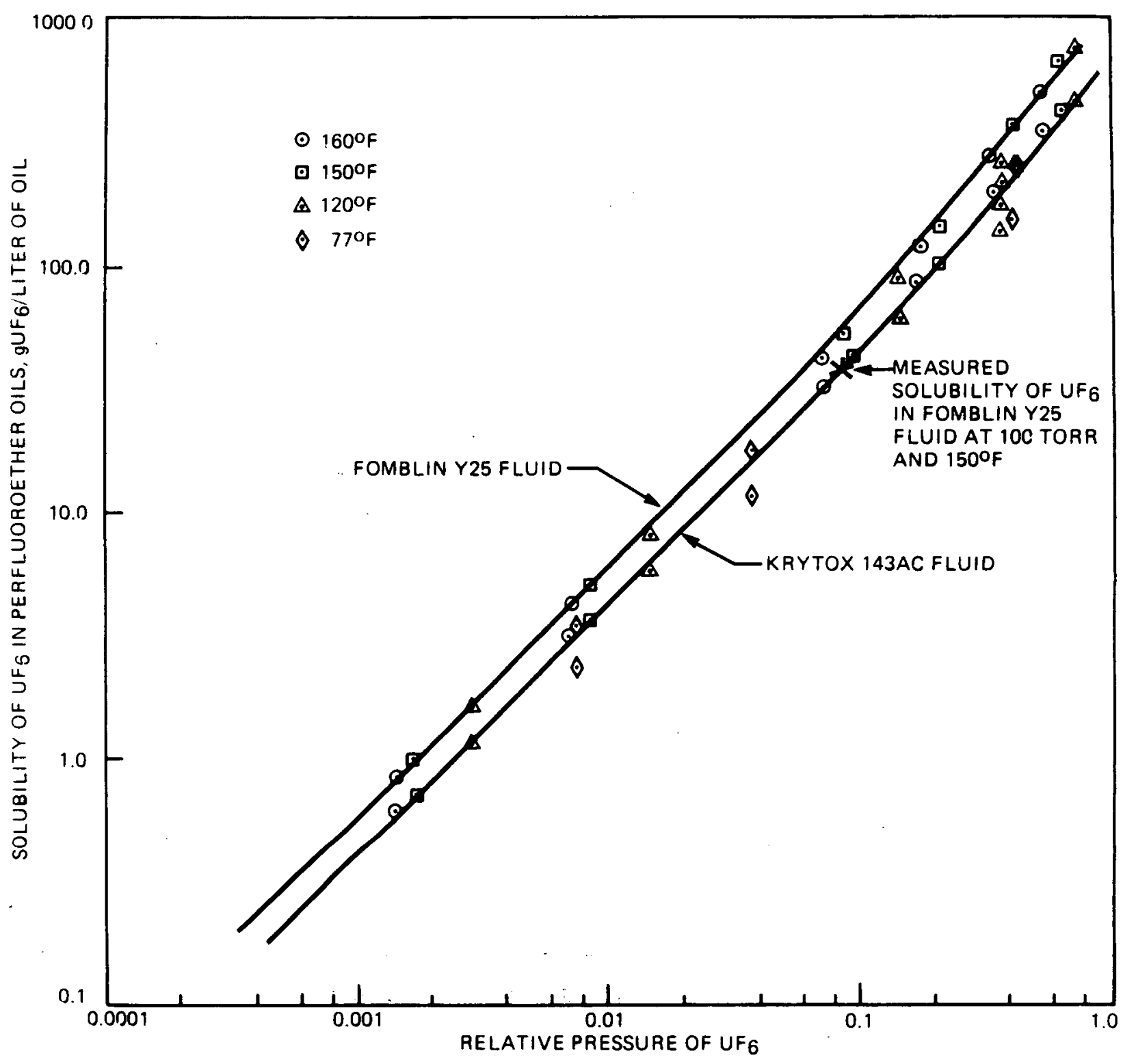

Figure 1

SOLUBILITY OF UF 6 KRYTOX 143AC AND FOMBLIN Y25

POLYPERFLUOROETHER FLUIDS AS A FUNCTION OF RELATIVE PRESSURE AT FOUR TEMPERATURES 
DWG. NO. K/G-84-2094

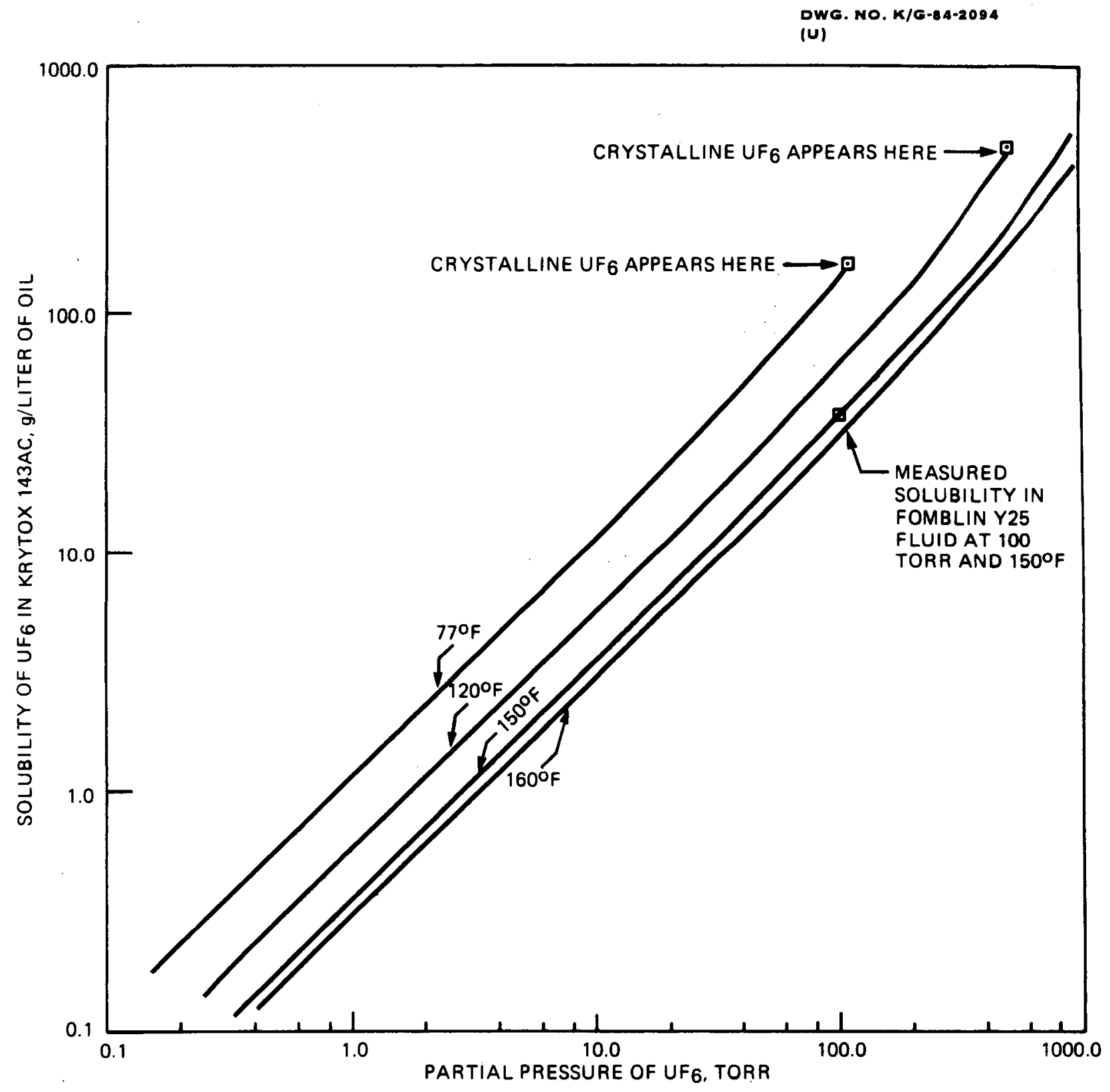

Figure 2

SOLUBILITY OF UF6 IN KRYTOX 143 AC FLUID 
DWG. MO. K/G-84-2096

(U)

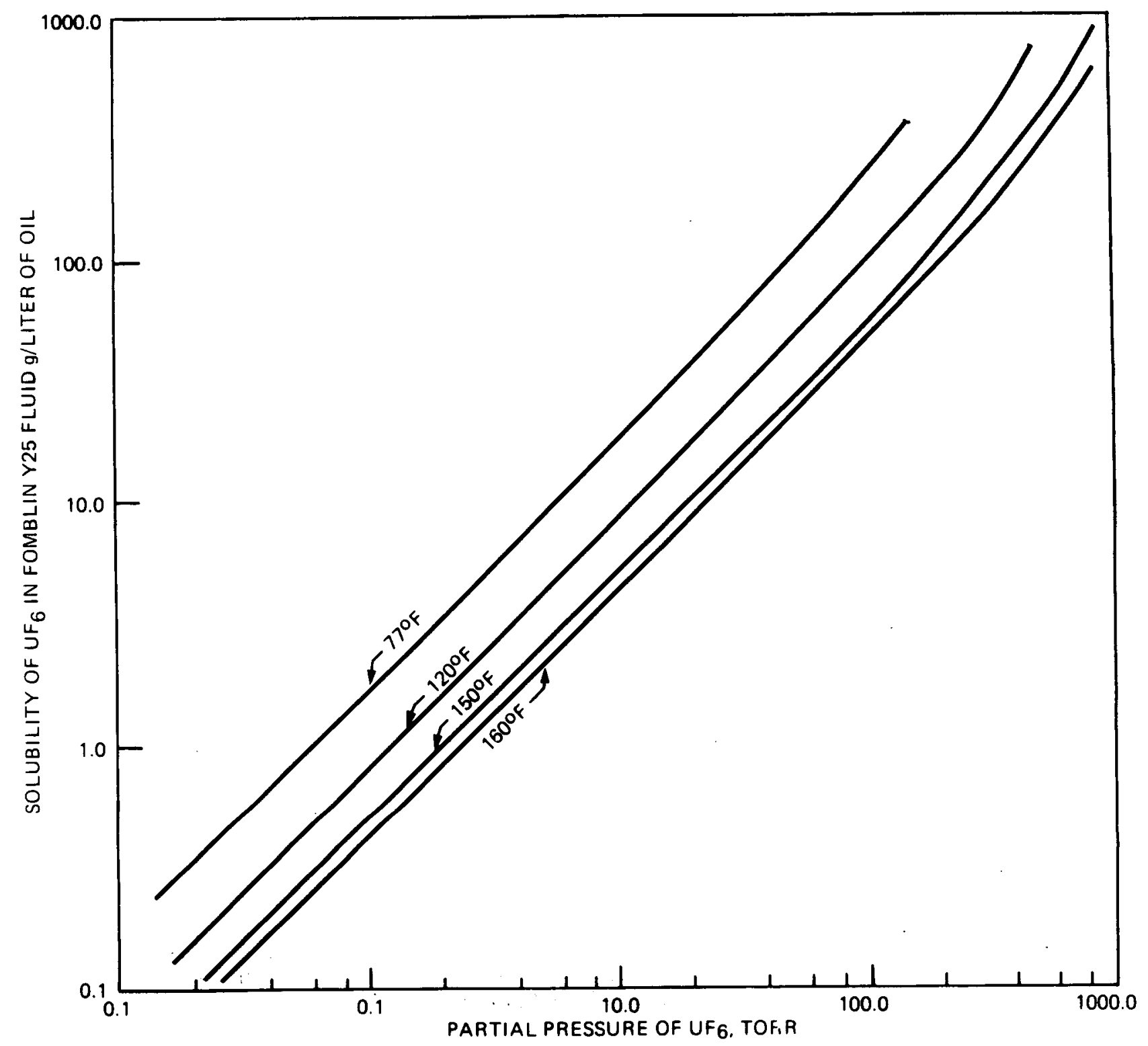

Figure 3

SOLUBILITY OF UF 6 IN FOMBLIN Y12 FLUID 
OWG. NO. K/G-84-200:

(u)

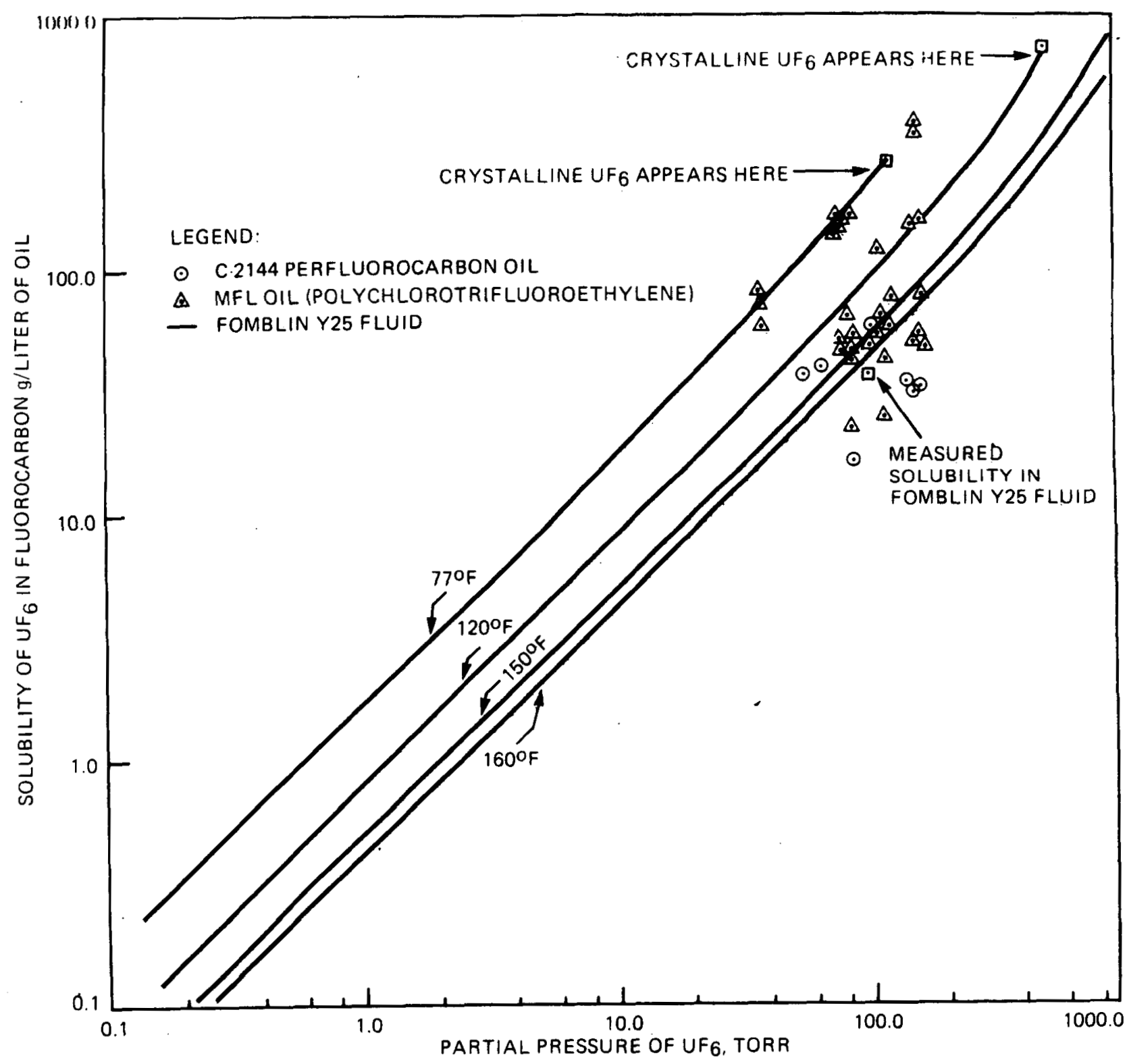

Figure 4

SOLUBILITY OF UF 6 IN C-2144 FLUOROCARBON OIL AND IN MFL OIL (POLYCHLOROTRIFLUOROETHYLENE) COMPARED WITH SOLUBILITY OF UF 6 IN FOMBLIN Y25 FLUID (NOTE TEMPERATURE RANGE FOR C-2144 OIL IS 140 TO $212^{\circ} \mathrm{F}$ AND FOR MFL OIL IS 100 TO $220^{\circ} \mathrm{F}$ ) 
DWG. NO. K/G-84-2097

(U)

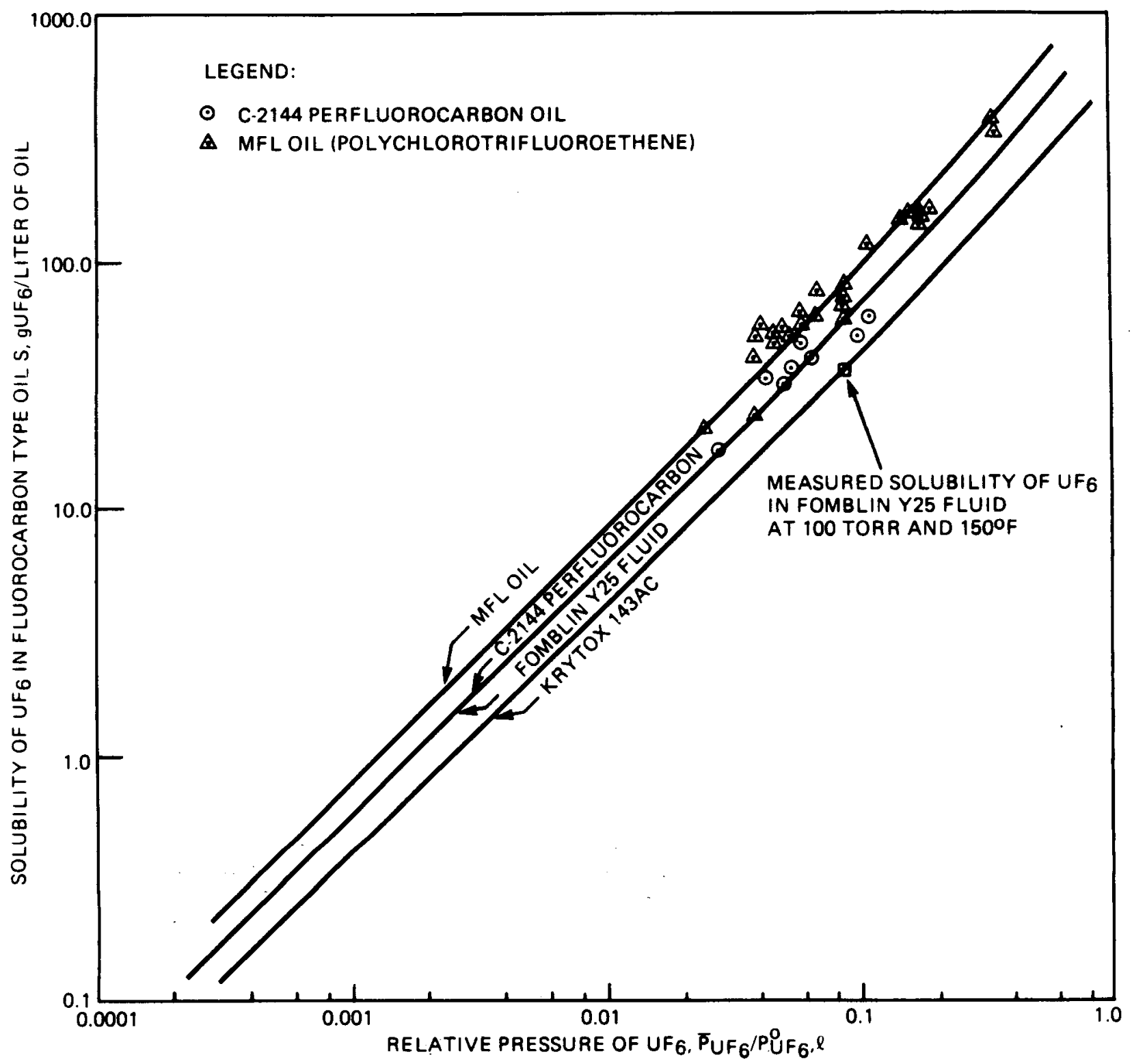

Figure 5

SOLUBILITY OF UF6 IN PERFLUOROCARBON TYPE FLUIDS 
relative pressure of the $\mathrm{UF}_{6}$ systematizes the data and clearly indicates that $\mathrm{UF}_{6}$ is more soluble in the MFL oil than in the C-2144 oil or the two perfluoroethers.

\author{
EFFECT OF DISSOLVED UF 6 ON THE OPERATING PRESSURE \\ OF A ROTARY SEAL VACUUM PUMP
}

In a rotary seal vacuum pump the working fluid provides both the lubrication and seal against atmospheric pressure or other pressure against which the pump is working. One of the properties which the working fluid must have is a lower vapor pressure than the required ultimate pressure in the system being pumped upon, since the pressure in the system cannot be reduced below the pressure exerted by the oil regardless of the pumping efficiency of the pump. In the uses projected for the pumps using the Fomblin Y25 fluids, the pressures at which operation will normally be carried out are in the order of 137 , m. For the pressure of the Fomblin Y25 oil to be this low, the concentration of the dissolved $U_{6}$ must be less than $0.1 \mathrm{~g}$ of $\mathrm{UF}_{6}$ per liter of oil. In practice, in an emergency the system will be permitted to operate until the pressure in the system being pumped upon reaches 9 torr total pressure. At this point all parts of the system are isolated from each other so that no more UF6 can reach the pumps. If one assumes that essentially all the 9 torr is due to $\mathrm{UF}_{6}$, the maximum concentration of $U_{6}$ in the Fomblin Y25 fluid would be between 4 and $8 \mathrm{~g}$ of UF6 per liter depending upon whether the pump was operating at its normal temperature of $160^{\circ} \mathrm{F}$ or minimum operating temperature of $120^{\circ} \mathrm{F}$.

Since the gas being drawn into the pumps may be fairly pure UF 6 , a stream of dry air is provided beyond the pumps in the discharge stream to keep the UF 6 partial pressure in the discharge stream from rising so high as to cause sufficient $U_{6}$ to dissolve in the oil to raise the oil pressure to unacceptable levels; i.e., 9 torr. In view of these controls it does not seem reasonable that the quantity of UF 6 dissolved in the Fomblin Y25 fluid in these pumps could exceed approximately 10 $\mathrm{g} / \mathrm{L}$ in a system isolation condition. Figures 6 and 7 show how this limiting pressure of 9 torr determines the quantity of UF 6 which can be dissolved in a liter of oil.

\title{
DISCUSSION OF THE RESULTS
}

The comparison of the estimated solubility of $\mathrm{UF}_{6}$ in the perfluoroethers, Krytox $A C$ and Fomblin Y25 fluid, at 100 torr UF 6 pressure and $150^{\circ} \mathrm{F}$ with the known solubility of $\mathrm{UF}_{6}$ in other fluorocarbon based oils ${ }^{h, "}$ " indicates that the estimations are reliable and accurate to within the spread of approximately $30 \%$ of the value normally obtained for this method of estimation with well-behaved materials of this kind. The degree of variation of the solubility with changes in temperature and partial and relative pressures of $\mathrm{UF}_{6}$ is correctly predicted. See Figure 5 . 
DWG. NO. K/G-84-2098

(u)

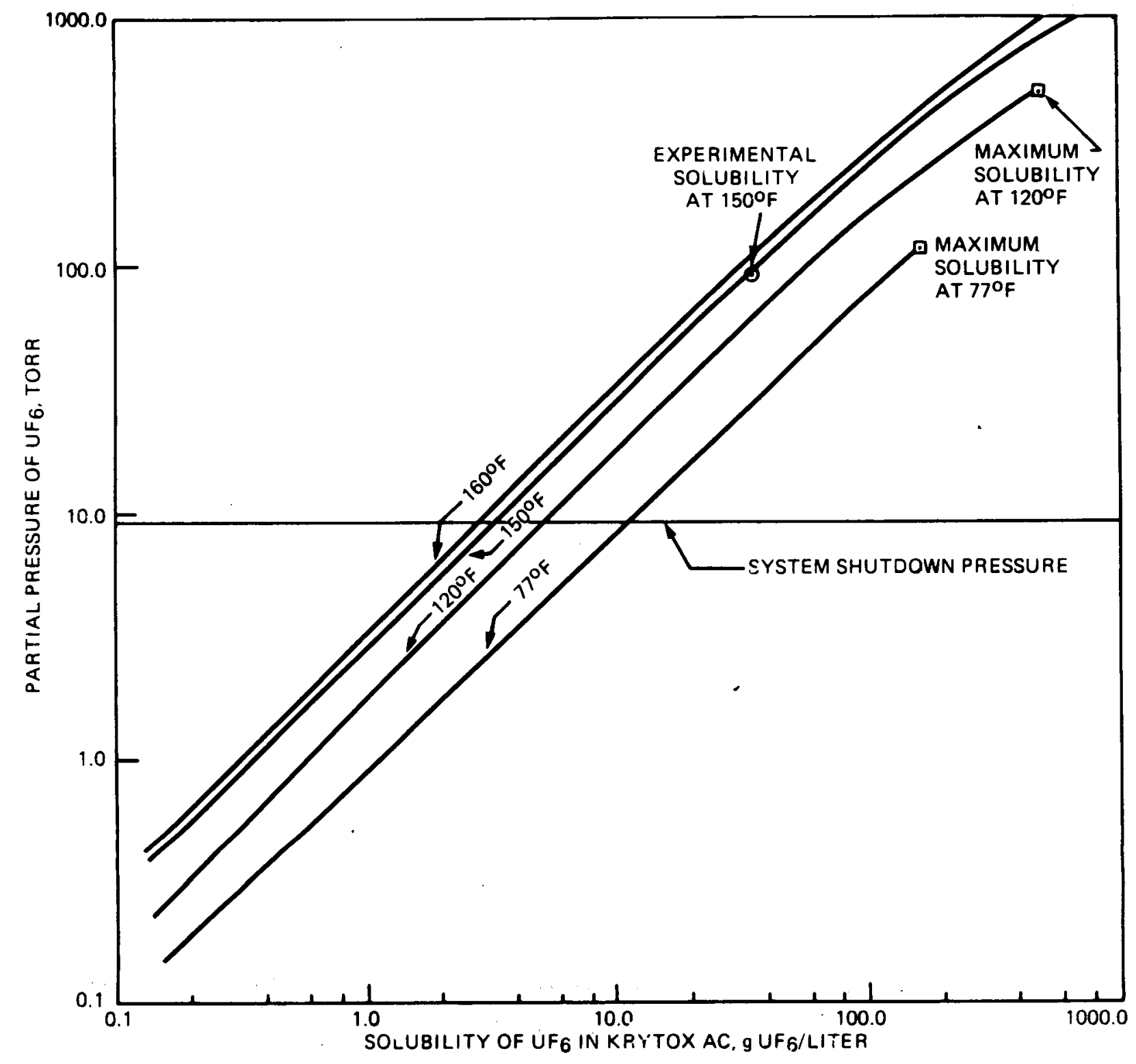

Figure 6

MINIMUM PUMP ENTRANCE PRESSURE AS A. FUNCTION OF DISSOLVED UF6 AND PUMP OPERATING TEMPERATURE 
DWG. NO. K/G-84-2098

(u)

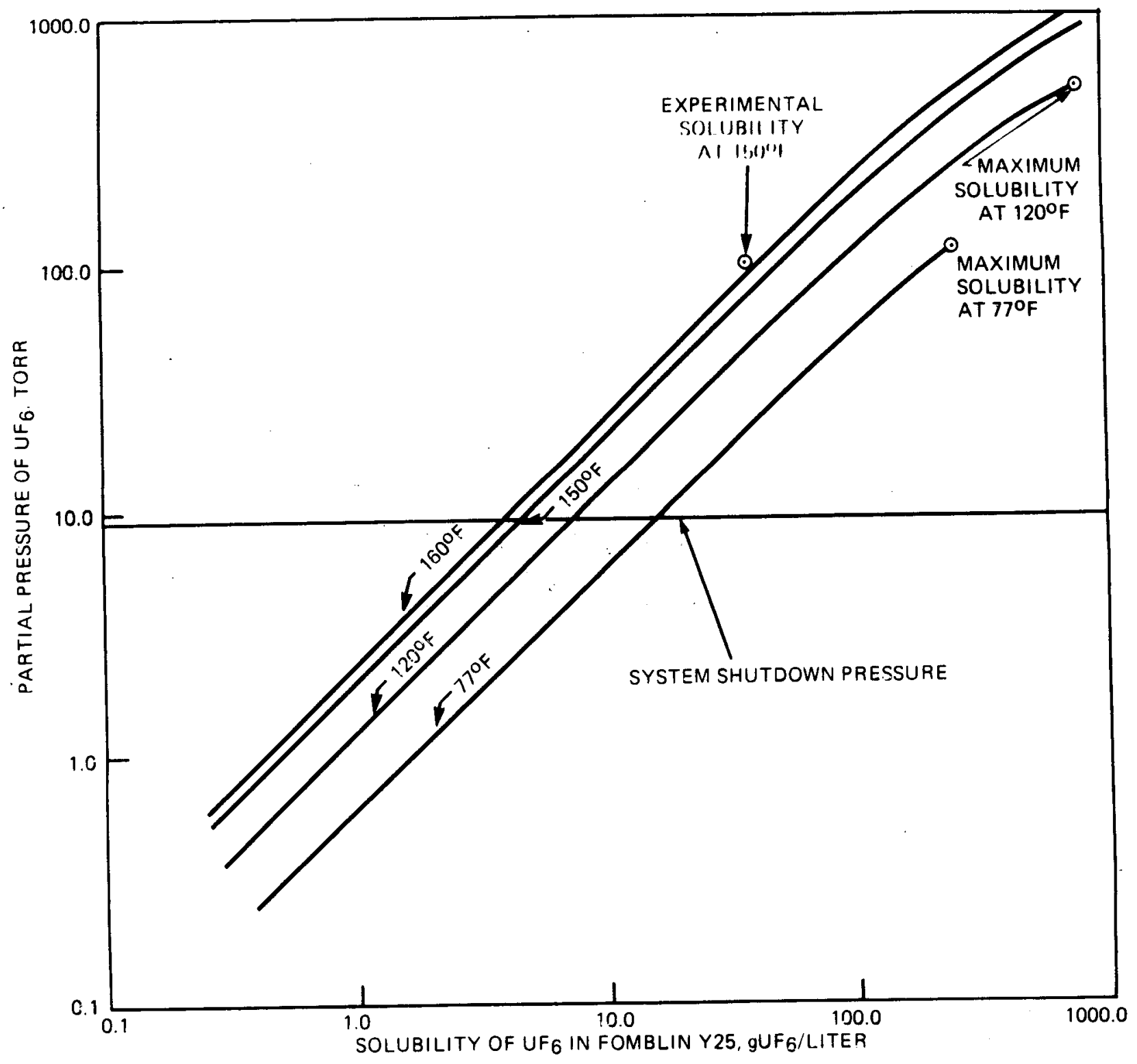

Figure 7

MINIMUM PUMP ENTRANCE PRESSURE AS A FUNCTION OF DISSOLVED UF 6 AND PUMP OPERATING TEMPERATURE 
At relative pressures of $\mathrm{UF}_{6}$ approaching 1.0 , the solubility of $\mathrm{UF}_{6}$ is quite large, reflecting the close to ideal mutual solubility of the components in each other. Only at and above the triple point temperature and pressure for $\mathrm{UF}_{6}$ can a relative pressure of 1.0 be reached since the relative pressure is determined by the lower of the ratios of the actual partial pressure or the pressure of the solid $\mathrm{UF}_{6}$ to the vapor pressure (or extrapolated vapor pressure) of liquid $U_{6}$ at the given temperature. Of course, pure solid $U_{6}$ will be deposited if the partial pressure of the $\mathrm{UF}_{6}$ in the vapor exceeds the vapor pressure of solid $\mathrm{UF}_{6}$ at the temperature. However, in an earlier section it was noted that system isolation from the pumps occurs if the pressure in the working part of the system exceeds 9 torr. This condition effectively defines the maximum quantity of $\mathrm{UF}_{6}$ which can be dissolved in the pump fluid at the time of isolation from the $U_{6}$ source to be less than $10 \mathrm{~g}$ $\mathrm{UF}_{6}$ per liter. Figure 7 permits determination of the maximum quantity of UF $_{6}$ dissolved per liter of Fomblin Y25 fluid for this or any other permissible operating pressure at temperatures of $160,150,120$, and $77^{\circ} \mathrm{F}$.

The system isolation control instrumentation thus constitutes the safety instrumentation for the system, preventing both (1) potential accidental damage to system components due to high pressure and (2) any possibility of depositing enough $\mathrm{UF}_{6}$ either by solubility in the pump fluid or condensation of solid to cause a nuclear criticality in case of rupture of the pump cooling system into the pump. This instrumentation will cause system isolation if either a breach occurs in the system being pumped upon or the flow of dry air to the pump discharge line is interrupted or fails to remove $U_{6}$ as fast as it enters the pumps.

\section{CONCLUSIONS}

The solubility of $\mathrm{UF}_{6}$ in polyperfluoroethers at a given temperature can be predicted from the physical and thermodynamic properties of the $\mathrm{UF}_{6}$ and the particular perfluoroether fluid involved to within about \pm 208 of the value. The dependence of the solubility on temperature and $\mathrm{UF}_{6}$ partial pressure are also correctly indicated.

The maximum solubility of $\mathrm{UF}_{6}$ in the Fomblin $\mathrm{Y} 25$ fluid employed in the rotary vane vacuum pumps in the BOP facilities for the GCEP at Portsmouth, Ohio, is effectively controlled by the system isolation instrumentation to be less than $10 \mathrm{~g}$ of $\mathrm{UF}_{6}$ per liter. 


$$
21 / 22
$$

\section{BIBLIOGRAPHY}

1. R. Dewitt, Uranium Hexafluoride: A Survey of the PhysicoChemical properties, GAT-280, Goodyear Atomic Corporation, Portsmouth, Ohio, August $12,1960$. p. 101.

2. J. H. Hildebrand and R. L. Scott, The Solubility of Nonelectrolytes, Third Edition, Reinhold publishing Corporation, New York (1950).

3. J. H. Hildebrand and S. E. Wood, J. Chem. Phys, 1, 817 (1947), J. H. Hildebrand, The Solubility of Nonelectrolytes, second Edition, Reinhold Publishing Corporation, New York (1936).

4. G. Scatchard, Chem. Reviews, 8, 321 (1931), Trans. Faraday Soc., 33, 160 (1937).

5. P. J. Flory, J. Chem. Phys. 9, 660 (1941), Ibid., 10, 51 (1942), Ibid., 13, 453-65 (19.45). $151(1942)$.

6. M. L. Huggins, Chem. Phys. 9, 440 (1941), J. Phys. Chem., 46,

7. J. L. Madix and N. S. Burwinkle, Previously Unreported Data, private communication from J. L. Madix.

$$
\begin{aligned}
& \text { 9. Ref. 1, p. } 106 . \\
& \text { 9. Ref. 1, p. } 105
\end{aligned}
$$

10. G. D. Oliver, H. T. Milton, and J. W. Grisard, "The Vapor Pressure and Critical Constants of Uranium Hexafluoride," J. Am. Chem. Soc., 75, 2827 (1953).

11. E. J. Barber, Relationship of pressure to Temperature Rise in Overfilled Cylinders, K/ET-194, Union Carbide Corp. Nuclear Div., Oak Ridge Gaseous Diffusion Plant, Oak Ridge, TN, May 18, 1979.

12. E. E. Sommers, Krytox Fluorinated Lubricants Technical Data: Appendix $I_{i}$ Table $1_{i}$ Table $2 ;$ Table $A_{i}$ Appendix III; Table $B_{i}$ Table $4 ;$ E. I. DeNemours and Company, Inc. Petroleum Chemicals Division, Wilmington, Delaware, January 1975.

13. Technical Bulletin Fomblin $Y$ Fluorinated Polyether Fluids, Montedison S.P.A., Milan, Italy. 
APPENDIX A

\begin{abstract}
PHYSICAL AND THERMODYNAMIC DATA REQUIRED FOR ESTIMATION OF THE SOLUBILITY OF URANIUM HEXAFLUORIDE

IN KRYTOX 143AC AND FOMBLIN Y25 FLUIDS
\end{abstract}

The data needed for the estimation of the solubility of $\mathrm{UF}_{6}$ in Krytox $\mathrm{AC}$ and Fomblin Y25 fluids include the following:

1. the vapor pressures of liquid and solid $U_{6}$ as a function of temperature,

2. the heat of vaporization of $\mathrm{UF}_{6}$,

3. the vapor pressures of the two polyperfluoroethers as functions of the temperature of estimations of the heats of vaporization,

4. the liquid densities of $\mathrm{UF}_{6}$, Krytox $A C$ fluid and Fomblin Y25 fluid, and

5. the number average molecular weights of the two fluoroethers.

Note: The molecular weight most often given for polymers is based on the viscosity which emphasizes the contribution of the high molecular weight molecules. In this case, the molecular weight needed is the one which influences the volatility. It can be estimated from the experimental heat of vaporization obtained from the slope of $1 \mathrm{n} \mathrm{P}$ versus $1 / \mathrm{T}$ plot and the incremental increase in the heat of vaporization associated with each incremental increase in the molecular weight. The use of the molecular weight determined in this way may result in a slight overstatement of the solubility. Use of the viscosity based molecular weights of ten leads to a gross understatement of the solubility.

The remaining parameters, such as the molar volumes and the solubility parameters, can be derived from the above.

Equations for these properties will be listed below for each material, respectively. The symbol $t$ will be used for degrees centigrade and the symbol $T$ for Kelvin.

Uranium Hexafluoride

vapor pressure of solid 10

$$
\log _{10} P(\text { torr })=6.38363+0.0075377 t-942.76 /(t+183.416)
$$

Vapor pressure of liquid 10

$$
\log _{10} P(\text { torr })=6.99464-1126.288 /(t+221.963)
$$


Density of liquid :

$$
\mathrm{p}(\mathrm{g} / \mathrm{ml})=1.670+0.15203\left(\mathrm{t}_{\mathrm{c}}-\mathrm{t}\right)^{1 / 2}
$$

$t_{c}$ is the critical temperature in degrees centigrade

Heat of vaporization (from slope of in $P$ vs $1 / T$ )

$$
\Delta H=7300 \text { calories per } \mathrm{g} / \mathrm{mol}
$$

Molecular weight

$$
\mathrm{M}_{\mathrm{UF}_{6}}=352
$$

KRYTOX 143AC FLUID :

Vapor Pressure and Heat of Vaporization

The vapor pressure of the Krytox Brand Fluids are shown in Figure $A-1$, in which the $\log _{10} P$ is shown as a function of $1 / T$. The heat of vaporization determined from the slope is 23,600 calories per $\mathrm{g} / \mathrm{mol}$.

Density of Liquid

$$
\mathrm{K}-\mathrm{AC}(\mathrm{g} / \mathrm{mol})=1.942-0.00172 \mathrm{t}
$$

Molecular Weight

If the heat of vaporization of polyperfluorogarbons and the heat of vaporization of perfluoroethers are plotted as a function of the molecular weight, the values tend to fall upon the same curve which becomes essentially linear as the molecular weight increases. By dividing the value of the heat of vaporization for a particular material by the limiting slope, of this curve, one obtains an estimate of the molecular weight. The value for perfluorocarbons is 800 calories per 50 molecular weight units. The effective molecular weight of the Krytox $A C$ fluid is approximately 1500 on this basis. The molecular weight determined from the viscosity is 5700 .

FOMBLIN Y25 FLUID ' '

Vapor Pressure and Heat of Vaporization

The vapor pressures of the Fomblin Brand Fluids are given in Figure A-2. The heat of vaporization of Fomblin Y25 fluid is 20,020 calories per $\mathrm{g} / \mathrm{mol}$.

Density of Liquid

$$
N_{\mathrm{F}-\mathrm{Y} 25}(\mathrm{~g} / \mathrm{mol})=1.925-0.00179 t
$$




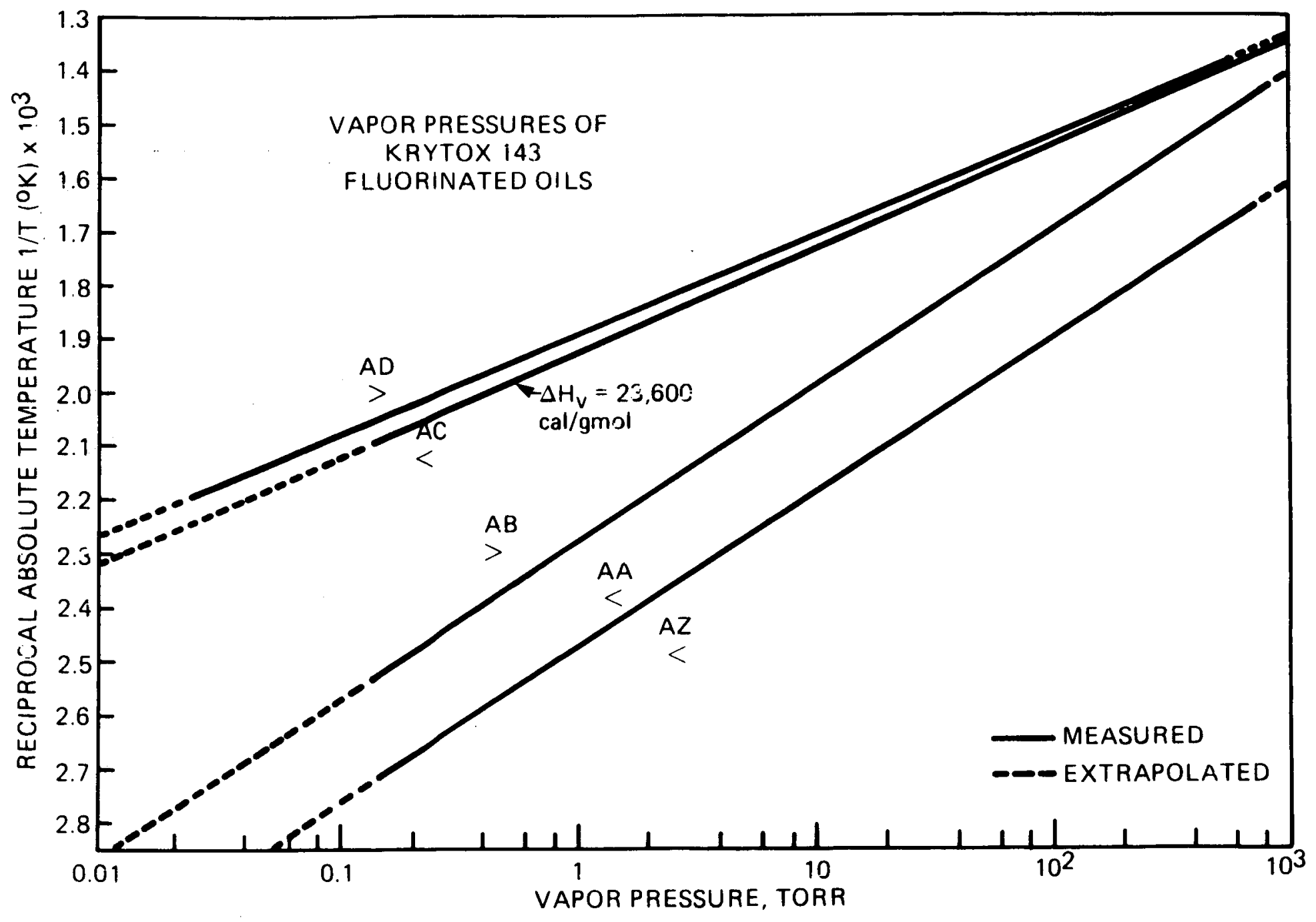

Figure A-1

VAPOR PRESSURE OF KRYTOX FLUIDS 


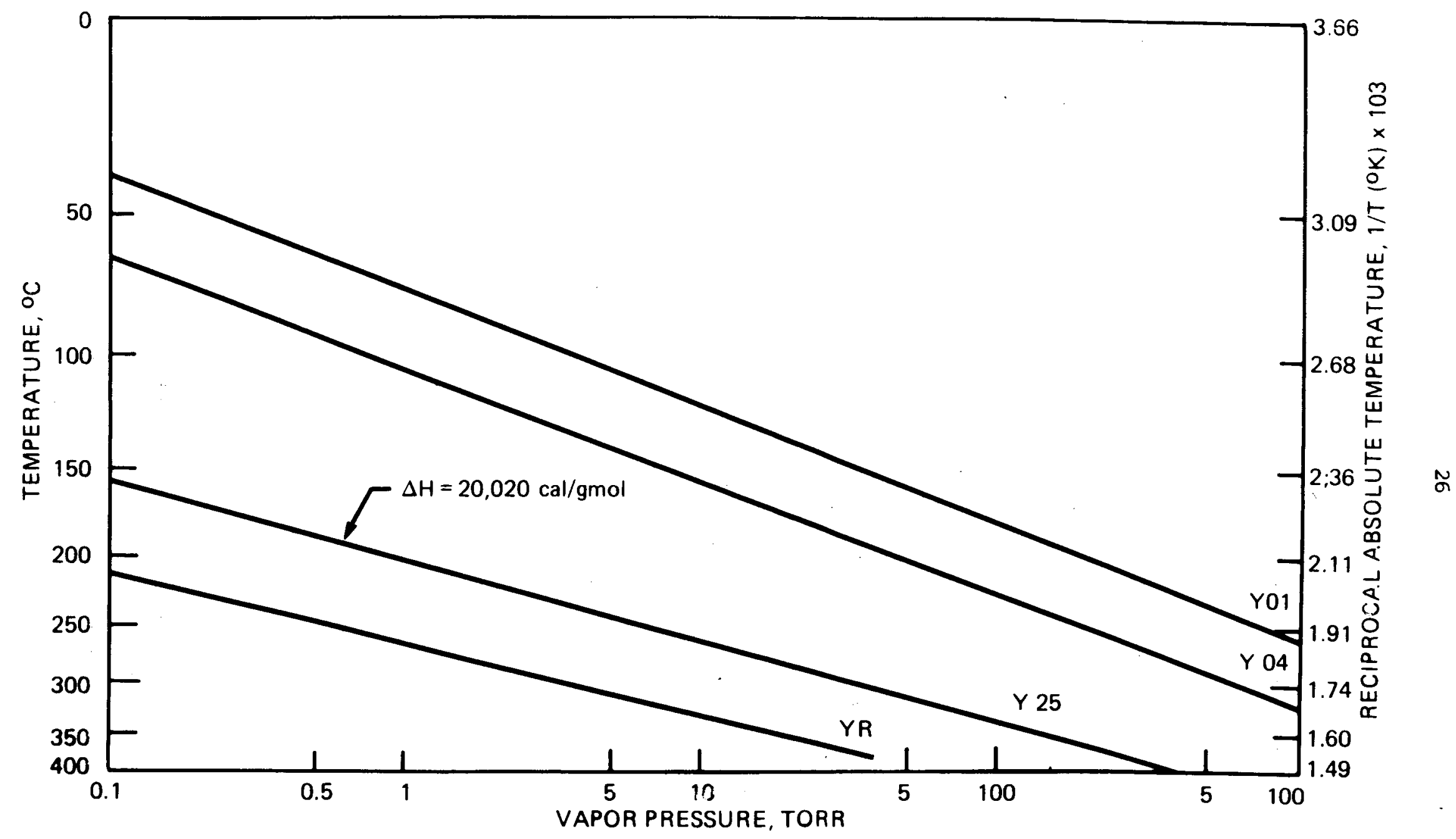

Figure A-2

VAPOR PRESSURE OF FOMBLIN FLUIDS 


$$
27128
$$

Note: The reference gives the density of the Fomblin Y25 fluid at only one temperature. The equation showing the temperature dependence is based on the behavior of a krytox fluid of similar molecular weight.

Molecular Weight

Using the same scheme as for the Krytox $143 \mathrm{AC}$, the molecular weight needed for these calculations is 1100. The molecular weight based on the viscosity is 3400 .

Data used in solubility estimation at $160,150,120$, and $77^{\circ} \mathrm{F}$

For $\mathrm{UF}_{6}$ :

\begin{tabular}{|c|c|c|c|c|}
\hline $\begin{array}{c}\text { Temperature, } \\
{ }^{\circ} \mathrm{F} \\
\end{array}$ & $\begin{array}{c}\text { Density, } \\
\mathrm{g} / \mathrm{ml} \\
\end{array}$ & $\begin{array}{c}\text { Molar volume, } \\
\mathrm{ml} \\
\end{array}$ & $\begin{array}{c}\delta\left(\mathrm{UF}_{6}\right)^{\prime} \\
(\mathrm{cal} / \mathrm{mol})^{1 / 2} \\
\end{array}$ & $\begin{array}{c}\text { Vapor } \\
\text { pressure, } \\
\text { torr } \\
\end{array}$ \\
\hline 160 & 3.588 & 98.10 & 8.213 & 1417.4 \\
\hline 150 & 3.620 & 97.22 & 8.256 & 1195.2 \\
\hline 120 & {$[3.717]$} & {$[94.70]$} & 8.386 & 686.3 \\
\hline 77 & {$[3.848]$} & {$[91.48]$} & 8.563 & 271.7 \\
\hline
\end{tabular}

[] indicates extrapolated values for liquid

For Krytox 143 AC fluid:

\begin{tabular}{|c|c|c|c|}
\hline $\begin{array}{c}\begin{array}{c}\text { Temperature, } \\
{ }^{\circ} \mathrm{F}\end{array} \\
\end{array}$ & $\begin{array}{c}\text { Density, } \\
\mathrm{g} / \mathrm{ml} \\
\end{array}$ & $\begin{array}{c}\text { Molar volume, } \\
\mathrm{ml}\end{array}$ & $\begin{array}{r}\delta(\mathrm{K}-\mathrm{AC}) \\
(\mathrm{cal} / \mathrm{ml}) 1 / 2 \\
\end{array}$ \\
\hline 160 & 1.820 & 824 & 5.27 \\
\hline 150 & 1.829 & 820 & 5.29 \\
\hline $\begin{array}{r}120 \\
77\end{array}$ & $\begin{array}{l}1.858 \\
1.899\end{array}$ & $\begin{array}{l}807 \\
790\end{array}$ & $\begin{array}{l}5.33 \\
5.40\end{array}$ \\
\hline
\end{tabular}

For Fomblin Y25 fluid:

\begin{tabular}{|c|c|c|c|}
\hline $\begin{array}{c}\text { Temperature, } \\
{ }^{\circ} \mathrm{F} \\
\end{array}$ & $\begin{array}{c}\text { Density, } \\
\mathrm{g} / \mathrm{ml} \\
\end{array}$ & $\begin{array}{l}\text { Molar volume, } \\
\mathrm{ml}\end{array}$ & $\begin{array}{r}\delta(F-Y 25) \\
(\mathrm{cal} / \mathrm{ml})^{1 / 2} \\
\end{array}$ \\
\hline 160 & 1.798 & 612 & 5.62 \\
\hline 150 & 1.808 & 609 & 5.64 \\
\hline 120 & 1.837 & 599 & 5.69 \\
\hline 77 & 1.899 & 585 & 5.76 \\
\hline
\end{tabular}




\title{
APPENDIX B
}

\begin{abstract}
SOLUBILITY OF UF 6 IN KRYTOX 143 AC AND FOMBLIN Y25 FLUIDS AT $160,150,120$, AND $77^{\circ} \mathrm{F}$
\end{abstract}

The equations presented in the second section of the report have been used to estimate the solubility of $U_{6}$ in Krytox $A C$ and Fomblin $Y 25$ fluids. The results of the calculation are summarized in this Appendix.

Table B-1. The solubility of $\mathrm{UF}_{6}$ at $160^{\circ} \mathrm{F}$

\begin{tabular}{|c|c|c|c|c|c|}
\hline \multirow{2}{*}{$\mathrm{UF}_{6}$} & \multirow{2}{*}{$\begin{array}{l}\text { pressure, } \\
\text { torr }\end{array}$} & \multicolumn{2}{|c|}{ Mol fraction $\mathrm{UF}_{6}$ in } & \multicolumn{2}{|c|}{ Solubility, g/liter in } \\
\hline & & Krytox AC & Fomblin $Y 25$ & Krytox AC & Fomblin Y25 \\
\hline & 2 & 0.00142 & 0.00145 & 0.61 . & 0.84 \\
\hline & 10 & 0.00708 & 0.00724 & 3.05 & 4.19 \\
\hline & 100 & 0.0686 & 0.0706 & 31.5 & 42.4 \\
\hline & 250 & 0.164 & 0.171 & 83.8 & 118.6 \\
\hline & 500 & 0.307 & 0.321 & 189.2 & 272 \\
\hline & 760 & 0.437 & 0.456 & 332 & 482 \\
\hline
\end{tabular}

Table B-2. The solubility of $\mathrm{UF}_{6}$ at $150^{\circ} \mathrm{F}$

\begin{tabular}{|c|c|c|c|c|c|}
\hline \multirow{2}{*}{$\mathrm{UF}_{6}$} & \multirow{2}{*}{$\begin{array}{l}\text { Pressure, } \\
\text { torr }\end{array}$} & \multirow{2}{*}{$\begin{array}{r}\text { Mol fra } \\
\text { Krytox AC } \\
\end{array}$} & \multirow{2}{*}{$\begin{array}{l}\text { ion } \mathrm{UF}_{6} \text { in } \\
\text { FombIin Y25 }\end{array}$} & \multicolumn{2}{|c|}{ Solubility, g/liter in } \\
\hline & & & & Krytox AC & Fomblin Y25 \\
\hline & 2 & 0.00163 & 0.00167 & 0.70 & 0.97 \\
\hline & 10 & 0.00814 & 0.00837 & 3.52 & 4.88 \\
\hline & 100 & 0.0787 & 0.0813 & 36.7 & 51.1 \\
\hline & 250 & 0.187 & 0.195 & 98.7 & 140 \\
\hline & 500 & 0.346 & 0.366 & 227 & 337 \\
\hline & 760 & 0.494 & 0.531 & 419 & 654 \\
\hline
\end{tabular}


Table B-3. The solubility of $\mathrm{UF}_{6}$ at $120^{\circ} \mathrm{F}$

\begin{tabular}{|c|c|c|c|c|}
\hline \multirow{2}{*}{$\begin{array}{c}\mathrm{UF}_{6} \begin{array}{l}\text { pressure, } \\
\text { torr }\end{array} \\
\end{array}$} & \multirow{2}{*}{$\begin{array}{r}\text { Mol fr } \\
\text { Krytox AC }\end{array}$} & \multirow{2}{*}{$\begin{array}{l}\text { Lon } \mathrm{UF}_{6} \text { in } \\
\text { Fomblin } \mathrm{Y}_{25}\end{array}$} & \multicolumn{2}{|c|}{ Solubility, g/liter in } \\
\hline & & & Krytox AC & Fomblin Y25 \\
\hline 2 & 0.00257 & 0.00270 & 1.12 & 1.59 \\
\hline 10 & 0.0128 & 0.0135 & 5.66 & 8.04 \\
\hline 100 & 0.122 & 0.129 & 60.6 & 87.0 \\
\hline 250 & 0.283 & 0.304 & 172 & 257 \\
\hline $494.5 *$ & 0.512 & 0.567 & 458 & 770 \\
\hline
\end{tabular}

* Maximum vapor pressure of $\mathrm{UF}_{6}$ at this temperature.

Table B-4. The solubility of $\mathrm{UF}_{6}$ at $77^{\circ} \mathrm{F}$

\begin{tabular}{|c|c|c|c|c|}
\hline $\begin{array}{c}\text { UF }_{6} \text { pressure, } \\
\text { torr }\end{array}$ & $\begin{array}{l}\text { Mol frac } \\
\text { Krytox AC }\end{array}$ & $\begin{aligned} \text { tion } \mathrm{UF}_{6} & \text { in } \\
\text { Fomblin } & \text { Y25 }\end{aligned}$ & $\begin{array}{l}\text { Solubility, } \\
\text { Krytox AC }\end{array}$ & $\begin{array}{l}\text { g/liter in } \\
\text { Fomblin Y25 }\end{array}$ \\
\hline 2 & 0.00513 & 0.00559 & 2.30 & 3.38 \\
\hline 10 & 0.0255 & 0.0278 & 11.7 & $17 \cdot 2$ \\
\hline 100 & 0.235 & 0.261 & 137 & 213 \\
\hline $111.8 *$ & 0.261 & 0.290 & 157 & 246 \\
\hline *Maximum & jor pressu & of $\mathrm{UF}_{6}$ at this & temperature. & \\
\hline
\end{tabular}




$$
31 / 32
$$

Table B-5. The relative pressure of $U_{6}$ for several temperatures and partial pressures of $\mathrm{UF}_{6}$

\begin{tabular}{|c|c|c|c|c|}
\hline $\begin{array}{c}\text { Temperature } \\
{ }^{\circ} \mathrm{F} \\
\end{array}$ & $\begin{array}{c}\text { UF }_{6} \begin{array}{l}\text { pressure } \\
\text { torr }\end{array} \\
\end{array}$ & $\mathrm{UF}_{6}$ & $\begin{array}{l}\text { liquid pressure } \\
\text { torr }\end{array}$ & Relative pressure \\
\hline \multirow[t]{6}{*}{160} & 2 & & 1417.9 & 0.00141 \\
\hline & 10 & & & 0.00705 \\
\hline & 100 & & & 0.0705 \\
\hline & 250 & & & 0.176 \\
\hline & 500 & & & 0.353 \\
\hline & 760 & & & 0.536 \\
\hline \multirow[t]{6}{*}{150} & 2 & & 1195.0 & 0.00167 \\
\hline & 10 & & & 0.00837 \\
\hline & 100 & & & 0.0837 \\
\hline & 250 & & & 0.209 \\
\hline & 500 & & & 0.418 \\
\hline & 760 & & & 0.636 \\
\hline \multirow[t]{5}{*}{120} & 2 & & 686.0 & 0.00292 \\
\hline & 10 & & & 0.0146 \\
\hline & 100 & & & 0.146 \\
\hline & 250 & & & 0.364 \\
\hline & $494.5^{\star}$ & & & 0.720 \\
\hline \multirow[t]{4}{*}{77} & 2 & & 271.7 & 0.00736 \\
\hline & 10 & & & 0.0368 \\
\hline & 100 & & & 0.368 \\
\hline & $111.8 *$ & & & 0.412 \\
\hline *Maxin & ór pressure & $\mathrm{UF}_{6}$ & at this tempera & e. \\
\hline
\end{tabular}


APPENDIX C

THE SOLUBILITY OF UF 6 IN FLUOROCARBON OIL C-2144 AND IN MFL OIL ( POLYCHLOROTRIFLUOROETHYLENE)

The solubility of $\mathrm{UF}_{6}$ in a perfluorocarbon with the empirical formula $\mathrm{CF}_{3}\left(\mathrm{CF}_{2}\right) 19 \mathrm{CF}_{3}$ has been measured at three temperatures. The results are tabulated in Table $\mathrm{C}-1$. Experimental measurements of the solubility of $\mathrm{UF}_{6}$ in a polychlorotrifluoroethylene with a molecular weight of $790 \pm 30$ have been made at five temperatures and are given here in Table C-2.

Table C-1. The solubility of $\mathrm{UF}_{6}$ in $\mathrm{C}-2144$ fluorocarbon oil

\begin{tabular}{|c|c|c|c|}
\hline $\begin{array}{c}\text { Temperature } \\
{ }^{\circ} \mathrm{F} \\
\end{array}$ & $\begin{array}{cc}\text { UF }_{6} & \begin{array}{l}\text { pressure } \\
\text { torr }\end{array} \\
\end{array}$ & Relative pressure & $\begin{array}{r}\text { Solubility } \\
\text { g/liter oil }\end{array}$ \\
\hline \multirow[t]{4}{*}{140} & 52.8 & 0.0528 & 35.9 \\
\hline & 63.1 & 0.0631 & 39.5 \\
\hline & 95.8 & 0.0957 & 49.1 \\
\hline & 105.6 & 0.106 & 57.5 \\
\hline 180 & 111.8 & 0.0571 & 46.7 \\
\hline \multirow[t]{4}{*}{212} & 83.6 & 0.0267 & 16.8 \\
\hline & 131.5 & 0.0419 & 33.6 \\
\hline & 147.5 & 0.0470 & 31.2 \\
\hline & 150.6 & 0.0480 & 32.4 \\
\hline
\end{tabular}


Table C-2. The solubility of $\mathrm{UF}_{6}$ in MFL oil

\begin{tabular}{|c|c|c|c|}
\hline $\begin{array}{c}\text { Temperature } \\
{ }^{\circ} \mathrm{F} \\
\end{array}$ & $\begin{array}{c}\mathrm{UF}_{6} \text { pressure } \\
\text { torr } \\
\end{array}$ & Relative pressure & $\begin{array}{l}\text { Solubility } \\
\text { g/liter oil }\end{array}$ \\
\hline \multirow[t]{12}{*}{100} & $\begin{array}{l}38.30 \\
38.30\end{array}$ & 0.0841 & $\begin{array}{l}57.5 \\
69.5\end{array}$ \\
\hline & 38.30 & & 77.9 \\
\hline & 74.02 & 0.163 & 155.8 \\
\hline & 74.53 & 0.164 & 141.4 \\
\hline & 72.46 & 0.159 & 134.2 \\
\hline & 74.53 & 0.164 & 147.4 \\
\hline & 76.60 & 0.168 & 149.8 \\
\hline & 79.19 & 0.174 & 154.6 \\
\hline & 80.74 & 0.177 & 155.8 \\
\hline & 80.74 & & 154.6 \\
\hline & 152.2 & 0.334 & 340.3 \\
\hline & 152.2 & & 378.7 \\
\hline \multirow[t]{5}{*}{140} & 82.30 & 0.0823 & 64.7 \\
\hline & 84.37 & 0.0843 & $67: 1$ \\
\hline & 106.6 & 0.107 & 112.6 \\
\hline & 139.2 & 0.139 & 146.2 \\
\hline & 150.1 & 0.150 & 151.0 \\
\hline \multirow[t]{13}{*}{180} & 83.85 & 0.0428 & 51.5 \\
\hline & 83.85 & & 41.9 \\
\hline & 83.85 & & 43.1 \\
\hline & 83.85 & & $44 \cdot 3$ \\
\hline & 83.85 & & 49.1 \\
\hline & 74.02 & 0.0378 & 49.1 \\
\hline & 76.08 & 0.0388 & $44 \cdot 3$ \\
\hline & 99.90 & 0.0510 & 49.1 \\
\hline & 112.3 & 0.0573 & 59.9 \\
\hline & 114.9 & 0.0587 & 53.9 \\
\hline & 124.2 & 0.0634 & 58.7 \\
\hline & 129.9 & 0.0663 & 73.1 \\
\hline & 152.7 & 0.0779 & 73.1 \\
\hline \multirow[t]{7}{*}{212} & 118.5 & 0.0378 & 24.0 \\
\hline & 147.5 & 0.0470 & 49.1 \\
\hline & 150.1 & 0.0479 & 52.7 \\
\hline & 83.85 & 0.0240 & 21.6 \\
\hline & 83.85 & 0.0240 & 21.6 \\
\hline & 124.7 & 0.0356 & 40.7 \\
\hline & 152.7 & 0.0436 & 46.7 \\
\hline
\end{tabular}


DISTRIBUTION

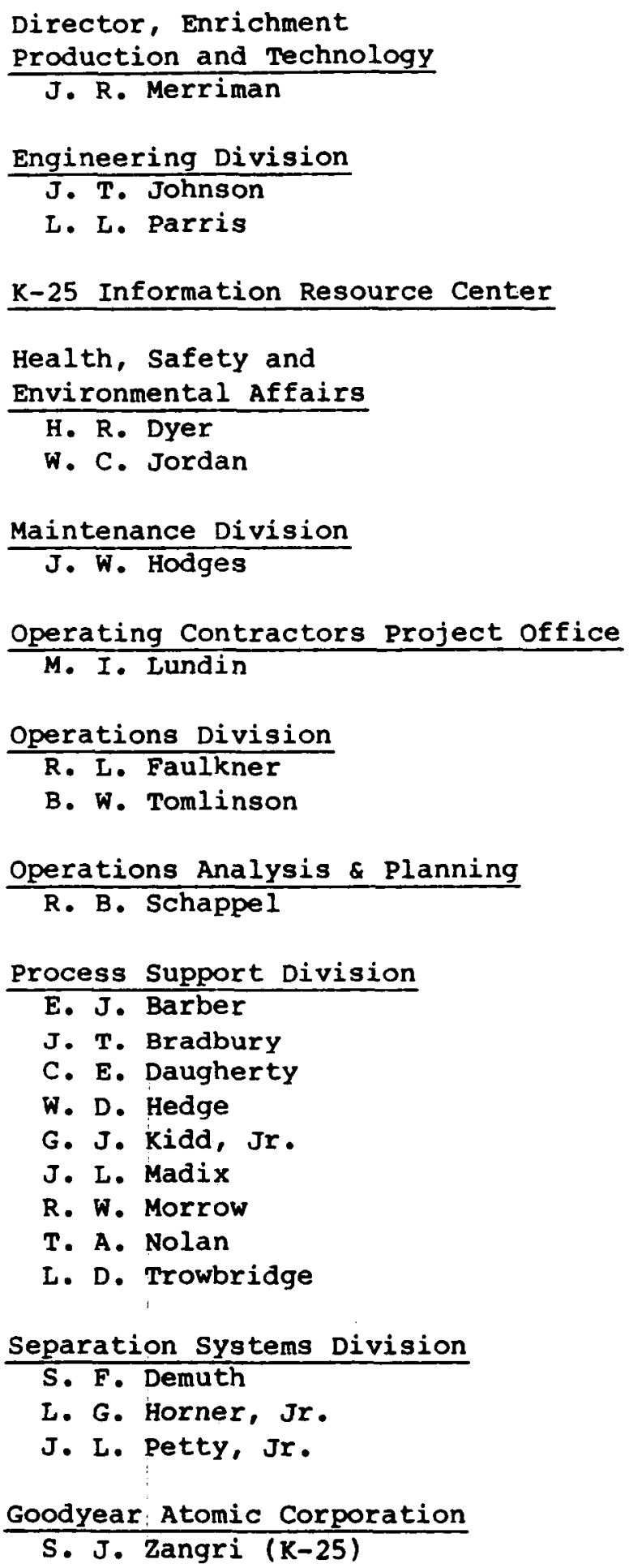

